\title{
PUBLIC ASSESSMENT OF THE PERFORMANCE DPRD's TANGERANG CITY IN THE PANDEMIC PERIOD OF 2020
}

\author{
by \\ William Yani WA ${ }^{1}$, Deddi Fasmadhy Satiadharmanto ${ }^{2}$, Retnowati WD Tuti $^{3}$ \\ Master of Administrative Sciences - FISIP, Muhammadiyah University Jakarta, \\ Jl. KH Ahmad Dahlan, Cirendeu, Kec. Ciputat, South Tangerang City, Banten, No. tel. (021) 7423273 \\ Email: ${ }^{1}$ williamyani29@gmail.com, ${ }^{2}$ fasmadhydeddi@gmail.com, ${ }^{3}$ retnowiwdtuti@yahoo.com
}

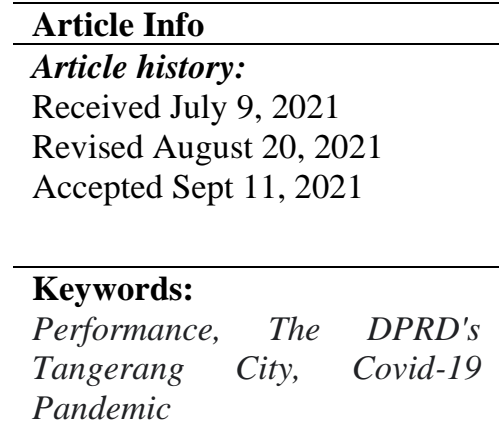

Corresponding Author:

Retnowati WD Tuti ${ }^{3}$

Master of Administrative Sciences - FISIP, Muhammadiyah University Jakarta,

Email: retnowiwdtuti@yahoo.com

\begin{abstract}
The one-year performance of The DPRD's Tangerang City for the 2019-2020 period is Influenced by the Covid-19 Pandemic. The analysis of the performance of The DPRD's Tangerang City is not only seen from the three functions of legislative members such as Legislation, Budget, and Supervision, but also during the Covid-19 Pandemic, performance is seen from the role of The DPRD's Tangerang City in dealing with this Pandemic and the adaptation of new values with technology compared to direct communication. This study was conducted with the aim of understanding and describing the performance of The DPRD's Tangerang City during the 2020 Covid-19 Pandemic and to find out and analyze the efforts made by The DPRD's Tangerang City members in dealing with the 2020 Covid-19 Pandemic. The method used in this research is a qualitative approach, the data collection is done based on interviews and literature study. This study in the finding that the performance of The DPRD's Tangerang City has declined in terms of quality and quantity due to the adapting situation during the Covid-19 Pandemic, but The DPRD's Tangerang City has shown a quick response in dealing with the Covid-19 Pandemic and shows high concern for the condition of the community.
\end{abstract}

This is an open access article under the CC BY-SA license.

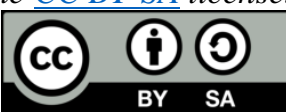

\section{INTRODUCTION}

On March 11, 2020, the World Health Organization (WHO) announced Corona Virus Disease (Covid 19) as a global pandemic, targeting public health, the global economy and global to local politics. This pandemic has become a test stone for the capability and quality of global, national and local government leadership.

When faced with extraordinary circumstances such as the COVID-19 pandemic, and high levels of volatility, uncertainty, complexity, ambiguity (VUCA) (Heinonen, Karjalainen, Ruotsalainen, \& Steinmüller, 2017)

Changes that are completely uncertain (VUCA) become permanent, the regional government system is faced with the Covid-19 Pandemic and is experiencing a new phase. The local government, the Tangerang City DPRD legislature and the Tangerang City Government executive are faced with challenges at the implementation level as the functions of local government are bound by Law Number 23 of 2014 concerning Regional Government.

In this context, parliament plays a central role not only in enacting emergency laws (Murphy 2020: 26-30), but in preventing the government from taking extreme measures that could plunge the country into authoritarianism (Freedom House 2021).

The extraordinary circumstances posed by the COVID pandemic have positioned the legislature at a crossroads in the Public Policy Factory. There is one side where the legislature must pass the local regulatory process and adopt accelerated emergency measures related to the Covid-19 pandemic with anti-democratic characteristics such as increased surveillance and restrictions on freedom (Chêne et al. 2020). On the other hand, the legislature must 
continue to function in political democratization, in this case protecting human rights, as well as maintaining a balance of checks and balances on the local government executives in the context of government obligations and responsibilities (Inter-Parliamentary Union and Office of the Executive).

In handling the Covid-19 pandemic in an emergency, the state is actually based on three approaches, namely:

1. health services;

2. fulfillment of fiscal needs; and

3. acceleration of handling in social activities.

The three approaches to handling the Covid-19 Pandemic can be seen in several policy products in the form of regulations issued by the Tangerang City Government as well as those in accordance with procedures following directions from the Indonesian Government in handling the Covid-19 Pandemic.

According to Murphy (2020:13), Parliamentarian around the world have simultaneously faced three kinds of challenges since the beginning of the pandemic. First, Parliamentarian have to decide on measures in real-time with great uncertainty over a long period of time. Second, they have to deal with highly technical topics and disagreements among experts about the appropriate response to dealing with public health and economic crises. Third, they are forced to work in conditions where Parliamentarian themselves risk getting sick and dying from carrying out their normal schedules and duties.

However parliaments decide to carry out their functions in times of crisis, it is always imperative that they do not abandon the core constitutional functions of legislation, executive oversight and citizen representation (Murphy 2020: 8).

Since the beginning of the COVID pandemic, the general trend has been the passing of repressive laws that do not have civil oversight or regular checks and balances through public participation, as well as the Provincial, Regency and City DPRDs in drafting regional regulations. Public Perceptions on the impact of COVID-19 on democracy and human rights, in its development there are obstacles to the birth of draft laws or derivatives below the draft regional regulations that tend to shackle freedom, are ambiguous but are interpreted as curbing the virus by political officials" (Repucci and Slipowitz 2020: 4).

Emergency measures The COVID-19 pandemic has resulted in an imbalance of power because in this case the executive institutions in most countries tend to position themselves, by overriding the legislature for various reasons until it is not clear. Crego and Kotanidis (2020) report that in many countries, the executive exercises special legislative powers through constitutional emergencies,

During the Covid-19 outbreak, State institutions regarding budgeting and budget management no longer went through the discussion mechanism in the DPRD which is generally carried out. President Jokowi issued a Regulation in Lieu of Law (Perpu) for handling Corona Virus Disease (COVID 19), in this case the portion of authority to make the Regional Government (Pemda) regulate one-way budgets without two-way reciprocity to the legislature. Vulnerable to fraud with the potential for misuse of the state budget in handling the Covid-19 outbreak.

This indicates that there are no checks and balances or periodic reviews of the Covid-19 pandemic emergency, the government feels only obliged to inform the policies they are doing, and forward them to the legislature, open emergency powers and martial law (Amnesty International 2020a)

In essence, the emergency powers granted to the executive are not limited, which can be abused to cancel all government affairs, including parliamentary activities, which are intended to provide oversight and balance to the executive.

However, in our research at the local level, in this case, the Tangerang City Government and the DPRD 's Tangerang City, on the contrary, work hand in hand to work together, they show a quick response and move quickly by increasing awareness of the spread of the Corona outbreak.

Based on the paradox of executive and legislative policies in Tangerang City, a research paper with the title Public Assessment of the Performance DPRD's Tangerang City was carried out in the 2020 Covid-19 Pandemic Period?

(1). What are the efforts made by the Tangerang City DPRD in dealing with the 2020 Covid-19 Pandemic?

(2). How is the performance of the Tangerang City DPRD during the 2020 Covid-19 Pandemic?

\section{Formulation of the problem}

Based on the background related to the supervisory function of the Tangerang City DPRD on the issue of the Covid 19 Pandemic, the problems in this writing are:

(1). What are the efforts made by the Tangerang City DPRD in dealing with the 2020 Covid-19 Pandemic?

(2). How is the performance of the Tangerang City Council during the PandemicCorona Virus Disease-2019 year 2020 ? 
International Journal of Social Science (IJSS)

Vol.1 No.3 October 2021, pp: 193-202

ISSN: 2798-3463 (Printed) | 2798-4079 (Online)

DOI: https://doi.org/10.53625/ijss.v1i3.412

\section{Research purposes}

The purpose of this study was to determine the performance of the Tangerang City DPRD in the Pandemic Period Corona Virus Disease-2019.

\section{LITERATURE REVIEW}

The People's Representative Council (DPR) of the Republic of Indonesia, the Regional People's Representative Council (DPRD) are part of the concept of separation of power by dividing power into executive, legislative and judicial branches. Legislative power cannot be combined with executive power, this is because to avoid tyranny in power. The legislature is given power as the basis for providing state administration through the formation of laws and regulations. In the administration of regional government, the Regional Representatives Council as a regional people's representative institution in the regional zoning of the Province to the Regency and City.

The three functions of the general embodiment of the role of DPRD are:

1. Regulators.

Regulation of all regional interests, including regional household affairs (autonomy) as well as central government affairs which are delegated to the regions for implementation (assistance tasks);

2. Public Policy

Formulating development policies and planning development programs in their regions;

3. Budget

Regional budget planning (APBD) in its role as a representative body

4. Supervision

The DPRD places itself as a balanced power that balances and exercises effective control over the Regional Head and all levels of the regional government.

Performance is the result of the function of a particular job or activity during a certain period of time. Performance Quality can be viewed from various perspectives according to the goals of each organization. Performance as a result of work that can be achieved by an organization or a group of people or individuals for the implementation of tasks that are the authority, obligations and responsibilities within a certain time in the right way. The reason is that every employee must have the ability and expertise to carry out the responsibilities entrusted to him (Sianipar and Entang, 2005: 67).

According to Armosudiro (2006:12) the organization is a collection of a group of people (two or more) who are formally united in a collaboration to achieve the goals that have been set. The formation of the organization because of the achievements as the basis and goals. Organizational performance according to Surjadi (2009: 7), organizational performance is the totality of the work achieved by an organization. The achievement of organizational goals means that the performance of an organization can be seen from the extent to which the organization can achieve goals based on predetermined goals.

The understanding of DPRD performance is as an employee's work performance and that work performance is assessed based on the job requirements set by the institution/organization.

In the Public Bureaucracy the indicators used to measure the performance of the public bureaucracy or organization according to Agus Dwiyanto et al ((2008:50-51) are as follows:

1. Productivity

A measure of the level of efficiency to service effectiveness. Productivity is generally understood as the ratio between inputs and outputs.

2. Quality of service

The level of community satisfaction becomes a reference for assessing the performance of public organizations.

3. Responsiveness

Organizations are capable of recognizing community needs by setting agendas and service priorities and developing public service programs in accordance with community needs and aspirations.

4. Responsibility

Adjustment of application activities of public organizations with correct administrative principles or in accordance with organizational policies, both explicit and implicit.

5. Public accountability

How much the policies and activities of public organizations are obedient to political officials elected by the people, represent the interests of the people.

Supervision 
Supervision is all activities to ensure and guarantee that the tasks/works have been carried out in accordance with the predetermined plan. The wisdom that has been outlined and the orders (rules) given. Supervision is basically directed entirely to avoid possible deviations or deviations from the objectives to be achieved.

Through supervision is expected to help implement the policies that have been set to achieve the planned goals effectively and efficiently. In fact, through supervision an activity is created that is closely related to the determination or evaluation of the extent to which work has been carried out. Based on this, in relation to the notion of supervision, that all activities carried out by the manager in an effort to ensure the actual results are in accordance with the planned results. Supervision is a function that ensures that activities can produce the desired results.

\section{RESEARCH METHODS}

In this study the method used is a qualitative method. This qualitative approach states that the investigation process is carried out through data collection, data processing, data analysis, and data inference based on methods and techniques approaches to answer a problem, (Zainal Arifin, 2012: 2).

The qualitative approach is also explained that a process used to collect and analyze information in order to improve our understanding of a topic (Imam Gunawan, 2013: 79). This research is in writing research based on qualitative descriptive which describes the general condition of the research area in words objectively, besides that it also describes behavior, perspective, motivation, and so on as a whole as well as in the form of words and language on an incident. special events means that the approach in this study does not use numbers (Burhan Bungin, 2003: 24). Qualitative research aims to collect actual information in detail, and describe the existing reality (Jalaludin Rakhmat, 2000: 25).

There are two sources of data used in this study, namely, first, interviews, and second, literature study. The first data source can be said to be primary data which is done by interviewing informants. Interviews were conducted using the directed interview method, meaning that this interview used the main points of the interview but still had an independent nature (Burhan Bungin, 2001: 135). While the next data source is secondary data, which is carried out to support primary data sourced from books, journals, documentation, work reports, mass media and research results related to this research.

After the data from the qualitative research has been collected, it will be analyzed through three stages, based on opinions Miles and Huberman, three stages are intended as follows: first, the data reduction stage, this stage consists of selecting data, transforming raw data such as typing interview transcripts, sorting, and arranging the data into different categories according to data sources; second, data presentation, this technique is done by compiling the data into an organized collection of information. The data is presented in the form of a narrative supported by pictures, charts and matrices; and third, the preparation of conclusions, this technique is carried out through the process of data analysis. The process of data analysis is carried out simultaneously with data collection. The interpretation of the analysis also needs to be done repeatedly so that the data reduction process can produce a summary of the findings,

In this study, the research material (object of research) is the Tangerang City DPRD Institute, with the unit of analysis being the performance of the DPRD during the Covid-19 pandemic. So that the object of research also explains that the time and place of research is at the Tangerang City DPRD Office. Based on this thorough understanding so that the research and writing process helps in explaining the research problems proposed in this study.

\section{RESULTS AND ANALYSIS}

\section{Efforts Made by DPRD in Dealing with the Covid-19 Pandemic}

The Tangerang City DPRD did show a quick response and moved quickly by making maximum efforts to break the chain of the Covid-19 virus pandemic. Various ways are carried out by taking concrete actions, individually the parties it supports, and the Tangerang City DPRD itself. Such as, starting from spraying disinfectant liquid, sharing food packages for residents affected by Covid-19, distributing personal protective equipment (PPE) in the form of masks and herbal medicines, also forming an officer unit (Satgas) to provide education to the public.

Tangerang City DPRD politicians are also willing to cut their salaries to deal with this virus. In addition, they also asked to postpone the renovation of the Tangerang City DPRD building. These funds are used for handling the corona virus (Tangerang7.com, 2020).

Shared awareness to break the pandemic chain is shown by decisions that allocate budgets, such as the construction of DPRD offices and the procurement of official vehicles for DPRD leaders. Chairman of the DPRD Gatot Wibowo explained, "The plan is that in 2020 there will be the construction of the DPRD's own office worth Rp. 40 billion, then the procurement of official vehicles for the leadership, this plan is based on the results of discussions we will transfer to handling Covid" (Gatot Wibowo, 2021).

The transfer of the 2020 council building construction budget, which is valued at Rp. 40 billion for the handling of COVID-19, is due to concern that the budget for handling COVID-19 in hospitals is only Rp. 28 billion, 
International Journal of Social Science (IJSS)

Vol.1 No.3 October 2021, pp: 193-202

ISSN: 2798-3463 (Printed) | 2798-4079 (Online)

DOI: https://doi.org/10.53625/ijss.v1i3.412

plus medical welfare of Rp. 7 billion. In addition to diverting the budget from the council building, a quick response was also carried out by deliberation for all council members to transfer their salary for one month in April 2020 to the relevant offices of the Tangerang City Government to help deal with the corona virus. Details of the assistance from the council's basic salary, which amounted to Rp. 1,575,000 per person, managed to collect around Rp. 100 million. With various additions made to increase the budget, the collected budget for handling COVID-19 is around 90 billion (mediaindonesia.com. 2020).

The Tangerang City DPRD also made efforts to cut non-priority regional budgets for the sake of dealing with Covid-19. This step was taken at the request of the Tangerang City Government to cut the spending budget for the prevention of Covid-19. In an effort to concentrate on dealing with the spread of the Covid-19 Pandemic, the Tangerang City DPRD also issued a decision that DPRD members are prohibited from making work visits (kunker) or comparative studies to other areas. This prohibition is carried out to maintain the health of legislators in order to avoid the corona virus (kabarbanten.minta-rakyat.com, 2020).

Togetherness in the work between the Tangerang City Government and the Tangerang City DPRD can be said to be good, even though the Tangerang City DPRD also often criticizes the performance of the Tangerang City Government. For example, criticizing the Social Safety Net (JPS) for Direct Cash Assistance (BLT) of Rp600,000 when it was not distributed to the local community even though the Large-Scale Social Restrictions (PSBB) had been extended for the third time. The DPRD has suggested that local governments collect aid data so that it is fast and on target, because we have agreed on a policy to carry out PSBB but the handling of social impacts must also be given immediately. This is a form of government attention (kabar6.com, 2020).

Analysis of DPRD Performance for One Year (2019-2020) during a Pandemic

The Covid-19 pandemic has caused the Central Government to the Regency/City level to refocus the budget in the context of handling and anticipating the impact of the Covid-19 Pandemic, including the City of Tangerang so that it has an impact on the development plans that have been designed. As the Regional Revenue and Expenditure Budget (APBD) which was originally planned for various physical or non-physical development programs that had been approved to be implemented in 2020 could not be implemented due to the Covid-19 pandemic, the budget was diverted for the handling of Covid-19 known as Refocusing.

According to the results of research in the field that the Tangerang City Government, especially the DPRD in terms of carrying out performance during Covid-19, made various efforts in handling Covid-19, such as: In this work, whether it's routine work or discussions, it's so free in terms of time, communication without distance so that discussions, meetings are maximized, but with this Covid, the agendas for meetings or discussions are very limited by the rules and regulations. rules according to the provisions of Covid.

The rules cover the room, the technical discussion that must go through the zoom meeting, even though the zoom meeting itself is something new for everyone. Resulting in the occurrence of many rigidities in the discussion meetings. So the meeting with the zoom meeting shows the obstacle factor in carrying out performance as a legislator.

The obstacle is that communicating with the Zoom meeting application is said to be not maximal, there are three findings, namely:

1. The difference is quite significant by communicating directly, such as for questions and answers in meetings, eventually sometimes it doesn't match what was answered, due to experiencing boredom, limited communicativeness, so that the results of the meeting ended up being satisfied, not satisfied, having to be satisfied.

2. When the meeting is no longer recommended to meet physically and then it is recommended to discuss online or zoom meetings, it has a weakness because it is constrained by the network which is sometimes disrupted which makes board members feel uncomfortable and because of the lack of information or data displayed online so that the quality of activities the discussion that was carried out became less effective, only formalities were important for the activities to be carried out.

3. Indeed, there are certain light discussions that can be carried out online or zoom meetings, but they are still considered less effective than offline, for example if meetings with the Office and the Ministry are only conducted normatively.

The Covid-19 Pandemic situation also cannot show the performance of legislators remains optimal and without any decrease in performance. This study also shows that based on the assessment of the interview results that the decline in performance can certainly be up to 50 percent, for example if from budgeting performance for example the targets have dropped drastically so that the Covid-19 pandemic is very influential, especially when the budget has decreased and there are also directions for refocusing. budget, the result of which is to cut the budget. But the targets regarding legislation, supervision are going well, but not optimal in terms of quality. 


\section{CONCLUSION}

Based on research conducted using interviews and literature study. In answering the research questions posed, namely what efforts were made by the Tangerang City DPRD in dealing with the 2020 Covid-19 Pandemic and how the Tangerang City DPRD performed during the 2020 Covid-19 Pandemic.

Tangerang City DPRD responded quickly and moved quickly, in carrying out humanitarian actions. The Tangerang City DPRD also showed a great understanding of the economic conditions of the Tangerang area and its people, so that social sensitivity was seen as people's representatives by diverting the budget for the construction of the DPRD building and official car vehicles for handling the Covid-19 pandemic. The Tangerang City DPRD on behalf of personally as a legislator, political party, and DPRD institution have shown their social sensitivity by also donating one month's funds in April to assist in handling Covid-19, as well as various other humanitarian aids.

Shared awareness to overcome the pandemic is also shown by In an effort to concentrate on dealing with the Covid-19 Pandemic, the Tangerang City DPRD issued a decision that DPRD members were prohibited from conducting work visits (kunker) or comparative studies to other regions. This prohibition is carried out to maintain the health of legislators to avoid the corona virus. Efforts to break the chain of transmission of Covid-19 have also caused DPRD members to anticipate meetings by using technological advances through the use of the zoom meeting application.However, it is undeniable that the Covid-19 pandemic has greatly affected the performance of Tangerang City legislators, for example, there may be a few weeks of absence of activity in the DPRD, thus affecting the number of activity agendas that have been set.

Changes in the technical mechanism of meetings that use online more through zoom meetings, of course, cause a decrease in the quality of the performance of legislators due to various technical problems in the field. Therefore, the Tangerang City DPRD needs to regulate the implementation or discussion of meeting activities so that the council remains comfortable and enthusiastic while at the same time adding adequate online meeting equipment or zoom meeting facilities.

In principle, the performance of the Tangerang City DPRD parliament during the Covid-19 pandemic was conditioned such as supervision, democratic accountability, transparency, legitimacy in all stages of the legislative process, with the Rule of Law, making laws and regulations such as evidence-based, rational, scientific literacy, and proper separation of powers. appropriate, and respect for human rights and the constitutional order during the Covid19 Pandemic. Ensuring that these principles continue to run during the Covid-19 period is a legislative obligation.

\section{References}

[1] Gustavo Gouvêa Maciel, thhelpdesk@ transparency.org, Legislative best practices in times of crisis FINAL, 1 June 2021

[2] Bar-Siman-Tov, I. (2020). Parliamentary Activities and Legislative Oversight during the Corona Virus Pandemic - A Comparative Review. Bar Ilan University Faculty of Law Research Paper No. 20-06. Available at SSRN: https://papers.ssrn.com/sol3/papers.cfm?abstract_id=3566948.

[3] Barkan, JD (ed.). (2009). Legislative power in developing African democracies (p.3333). Boulder: Lynne Rienne . Publisher

[4] WHO (2020). Coronavirus Situation Report, No, 41, 1 March 2020,https://www.who.int/docs/defaultsource/coronaviruse/situationreports/20200301-sitrep-41-COVID-19.pdf?sfvrsn=6768306d $>$ (27 October 2020).

[5] VDem Institute (2020). Pandemic Setback: Democracy and Disinformation Seven Months Entering the Covid-19 Pandemic, 2 October 2020 https://www.v-dem.net/media/filer_public/37/de/37defb66-9457-4eeb-887af0c168dc4365/v-dem_policybrief -25_201002_v2.pdf (4 October 2020).

[6] Greene, A. (2020). Emergency Force in a Time of Pandemic. Bristol: University of Bristol Press.

[7] Murphy, J. (2020). Parliament and Crisis: Challenges and Innovation. Parliamentary Primer No.1.https://www.idea.int/sites/default/files/publications/parliaments-and-crisis-challenges-and-innovations.pdf.

[8] Ginsburg, T. \& Versteeg, M. (2020). Bound Executives: The Power of Emergency during a Pandemic. Virginia Public Law and Legal Theory Research Paper No. 2020-52, University of Chicago, Public Law Working Paper No. 747, available at SSRN: http://dx.doi.org/10.2139/ssrn.3608974.

[9] HRW (2020). Turkmenistan Denies Obvious Covid-19 Outbreak, 27 June 2020,https://www.hrw.org/news/2020/06/27/turkmenistandeniesapparent-covid-19-outbreak (4 October 2020).

[10] Ginsburg, T. \& Versteeg, M. (2020). Bound Executives: The Power of Emergency during a Pandemic. Virginia Public Law and Legal Theory Research Paper No. 2020-52, University of Chicago, Public Law Working Paper No. 747, available at SSRN: http://dx.doi.org/10.2139/ssrn.3608974.

[11] Waismel-Manor, I. Bar-Siman-Tov, I. Rozenberg, O. Levanon, A. Benoît, C. \& Ifergane, G. (2020). Covid-19 and Legislative Activity: A Cross-Country Study. Bar Ilan University Faculty of Law Research Paper No. 20-12, available at https://dx.doi.org/10.2139/ssrn.3641824. 
International Journal of Social Science (IJSS)

Vol.1 No.3 October 2021, pp: 193-202

ISSN: 2798-3463 (Printed) | 2798-4079 (Online)

DOI: https://doi.org/10.53625/ijss.v1i3.412

[12] Lührmann, A. Edgell, AB \& Maerz, SF (2020). Pandemic Throwback: Is Covid-19 Risking Democracy? Policy Summary, V-Dem Institute.

[13] Radojevic, I. \& Stankovic, N. (2020). Parliament's Response to Covid-19 and the State of Emergency in the Western Balkans. First Report. Westminster Foundation for Democracy.

[14] Knaus, C. (2020). Calls for an end to 'undemocratic parliamentary delays. 10 May 2020.https://www.theguardian.com/ australianews/2020/may/11/calls-to-end-undemocratic-adjournment-ofparliament (9 September 2020).

[15] Ginsburg, T. \& Versteeg, M. (2020). Bound Executives: The Power of Emergency during a Pandemic. Virginia Public Law and Legal Theory Research Paper No. 2020-52, University of Chicago, Public Law Working Paper No. 747, available at SSRN: http://dx.doi.org/10.2139/ssrn.3608974.

[16] Mukherji, R. (2020). Covid vs. Democracy: India's Illiberal Medicine. Journal of Democracy, 31(4): 91-105.

[17] Verma, M. (2020). House of Representatives during a Pandemic. Economics and Politics Weekly, 55 (24), June $13,2020$.

[18] Wire (2020). DPR Monsoon Session Begins Amid Many Changes Due to the COVID-19 Situation, September 14, 2020, https://thewire.in/government/parliaments-monsoon-session-starts-covid-19-situation-question-hour (October 20, 2020) .

[19]FreedomHouse (2020). Freedom in the World - Democratic Republic of the Congo,https://freedomhouse.org/country/democraticrepubliccongo/freedom-world/2020 (1 November 2020).

[20] Ahmad, LB (2020). Covid-19: an extension of the state of health emergency. 23 April 2020,https://www.aa.com.tr/fr/afrique/rdc-covid19prorogation-de-1\%C3\%A9tat-durgence-sanitaire/1816480 (6 September 2020).

[21] Chahed, N. (2020). DRC: extension of the health emergency for 15 days. 23 May 2020,https://www.aa.com.tr/fr/afrique/rdcprorogation-de-1\%C3\%A9tat-durgence-sanitaire-de-15-jours/1851663 (6 September 2020).

[22] Mikanda, J. (2020). Covid19: National Assembly forms commission to assess government action, 11 June 2020,https://cas-info.ca/ 2020/06/covid19-lassemblee-nationale-met-en-place-une-commission-afin-devaluer-les -actions-du-gouvernement/ (6 September 2020).

[23] Global Democratic Countries Index (2019), https://www.idea.int/gsod-indices/about\#Effective\%20Parliament (14 September 2020).

[24]FOPH (2020). Coronavirus: Measures and Procedures,https://www.bag.admin.ch/bag/en/home/krankheiten/ausbruecheepidemienpandemien/aktuelleausbrueche-epidemien/novel-cov/massnahmen-des-bundes.html (22 October 2020 ).

[25] Switzerland Information (2020). Swiss parliament extends coronavirus relief package, 5 May 2020,https://www.swissinfo.ch/eng/politics/signoffsession_swiss-parliament-extends-coronavirus-reliefpackage/45737938 (22 October 2020).

[26] De Vrieze, F. (2020). There is no quarantine for democracy. April 21, 2020, https://www.wfd.org/2020/04/21/noquarantine-for-democracy/ (September 3, 2020).

[27] Hasan, AM (2020). Budget politics in dealing with Covid-19 in Indonesia. 14 September 2020,https://indonesiaatmelbourne.unimelb. edu.au/budget-politics-in-indonesias-covid-19-response/(22 October 2020).

[28] Lührmann, A. Edgell, AB \& Maerz, SF (2020). Pandemic Throwback: Is Covid-19 Risking Democracy? Policy Summary, V-Dem Institute.

[29] WHO (2020). Brazil Covid information,https://covid19.who.int/region/amro/country/br (14 November 2020).

[30] Smith, AE (2020). Brazilian Populist Playbook, Covid vs. Democracy. Journal of Democracy. 31(4): 76-90.

[31]London, E. (2020). Another Health Minister in Brazil Quits Amid the Chaos of the Coronavirus Response. The New York Times, May 15, 2020, https://www.nytimes.com/2020/05/15/world/americas/brazil-health-ministerbolsonaro.html (October 3, 2020).

[32] Reuters staff (2020). Brazilian Senate approves State of Emergency to combat coronavirus, 20 March 2020,https://www.reuters.com/article/us-health-coronavirus-brazil-emergency-idUSKBN2172G1 (16 October 2020).

[33] Agência Brasil (2020). Camara aprova Programa Emergencial deManutenção do Emprego e da Rendra. 28 May 2020.https://agenciabrasil. ebc.com.br/politica/noticia/2020-05/camara-aprova-programa-emergencial-demanutencao-do-emprego-e-da-renda(12 October 2020). 
[34]Meyer, EPN \& Bustamante, T. (2020). Authoritarianism Without Emergency Powers: Brazil Under 19.https://verfassungsblog.de/authoritarianism-without-emergency-powers-brazil-under-covid-19/ (3 October 2020).

[35] WHO (2020) Nepal Covid Information, https://covid19.who.int/region/searo/country/np.

[36] Devkota K. (2020) Responses to COVID-19 by emergency or inappropriate legislation, threats to democracy, case study Nepal with post-legislative oversight of the Infectious Diseases Act, 1964.

[37] Oxford Analytics (2019). Ukraine enters a new territory with a parliamentary majority. Expert Briefing,https://doi.org/10.1108/OXAN-DB245410.

[38] Felix Uhlmann \& Eva Scheifele, 'The Legislative Response to the Coronavirus (Switzerland)' (2020) Theory and Practice

[39] Maciej Serowaniec \& Zbigniew Witkowski, 'Can Legislative Standards Be Subdued? 'Quarantine'? Functions of the Sejm Tablet in Poland in the COVID-19 Era' (2020) Legislation Theory and Practice, doi:10.1080/20508840.2020.1805851.

[40] Constitution Magazine, Number 158, April 2020

[41] Aminudin, Supervisory Function of the DPRD in Realizing Good Governance, EJurnal Katalogis, No.3 (12) of 2015.

[42] Hasibuan, M. (2017). Management, Basic Understanding and Problems. Jakarta: Earth Literacy.

[43] Wiandari, IAA, and Darma, GS (2017). Leadership, Total Quality Management, Employee Productive Behavior, Employee Performance and Company Performance, Journal of Management \& Business, 14 (2): 61-78.

[44] Arikunto. Research Procedure A Practical Approach. Jakarta: Rineka. Create. (2016).

[45] Bungin, Burhan, Qualitative Research Methodology, (Jakarta: Raja Grafindo Persada, 2003).

[46] Gunawan, Imam, Qualitative Research Methods Theory and Practice, (Jakarta: Bumi Aksara, 2013).

[47] Haryoto, Edie, Pambagio, Agus, and Wasiat, Safira, Covid-19 Public Policy, Jakarta: RM Books, 2021.

[48] Results of an interview with Agus Sugiono, Secretariat of the Tangerang City DPRD Council (Sekwan), Tuesday 27 July 2021, at the Tangerang City DPRD Office.

[49]Results of an interview with Gatot Wibowo, Chairman of the Tangerang City DPRD, Tuesday 27 July 2021, at the Tangerang City DPRD Office.

[50] esults of an interview with Diki Rizki Abadi, Head of Sub-Section (Head of Subdivision) for the Tangerang City DPRD Session, Tuesday 27 July 2021, at the Tangerang City DPRD Office.

[51] Results of an interview with Miharja Adi Muhammad, Head of Sub-Section (Head of Sub-Section) for Budgeting Facilitation for the Tangerang City DPRD, Tuesday 27 July 2021, at the Tangerang City DPRD Office.

[52] Results of an interview with Sumarti, Chairman of Commission IV DPRD for Development, Tangerang City, Tuesday 27 July 2021, at the Tangerang City DPRD Office.

[53] Kabarbanten, Work Visits Prohibited, Tangerang City DPRD Members Focus on Discussing LKPj Tangerang Mayor 2019, in https://kabarbanten.minded-rakyat.com/seputar-banten/pr-59625478/dilarangkunjungan-kerja-member-dprd-kota-tangerang-fokus-bahas-lkpj-wali-kota-tangerang-2019, accessed July 31, 2021, at 21:48 WIB.

[54] Kartini, Wijoyo, Eriyono Budi, Istifada, Rizkiyana, Wibisana, Elang, Nuraini, and Nainar, Azizah Al Ashari, Health Counseling in Efforts to Change Behavior to Prevent Covid-19 Transmission in Tangerang City, Banten, Journal of Community Service (JAM), Vol. 2, No. 1, (2021), inhttp://openjournal.wdh.ac.id/php/ JAM/article/view/123, accessed July 31, 2021 , at $21: 24$ WIB.

[55] Kontan.co.id, the death toll from corona in Tangerang City has increased to 4 people, in https://regional.kontan.co.id/news/korbanmeninggal-hasil-corona-di-kota-tangerang-berikut-jadi-4-orang, accessed 22 July 2021, 22:55 WIB.

[56] Liputan6.com, Depok Mayor Explains the Conditions of His Citizens Infected with the Corona Virus,https://www.liputan6.com/regional/read/4192094/wali-kota-depok-beberkan-condition-warganya-yangterdalam-virus-corona, accessed 22 July 2021, 22:28 WIB.

[57] mediaindonesia.com, Overcoming Corona, Tangerang City DPRD Collects Sumantri's Salary, in https://mediaindonesia.com/megapolitan/301755/atasi-korona-dprd-kota-tangerang-kumpulkan-gaji, accessed July 31, 2021, 22:24 WIB.

[58] Rakhmat, Jalaludin, Communicative Research Methods, (Bandung: Rosda Karya Youth, 2000).

[59] Sarofah, Riska, Arlina Wati, Mega Dewi, and Fadli, Yusuf, Implementation of Large-Scale Social Restriction Policies in Tangerang City, Reform, Scientific Journal of Social and Political Sciences, Vol 11, No 1 (2021) in https://jurnal.unitri.ac.id/index.php/reformasi/article/view/2095, accessed July 31, 2021, at 21:21 WIB.

[60] Tangerang7.com, Tangerang City DPRD Efforts to Break the Covid-19 Chain, inhttps://tangerang7.com/dprd-kotatangerang-Efforts-breaking-rantai-covid-19/, accessed July 31, 2021 at 21:48 WIB. 1945 Constitution 
International Journal of Social Science (IJSS)

Vol.1 No.3 October 2021, pp: 193-202

ISSN: 2798-3463 (Printed) | 2798-4079 (Online)

[61] Law Number 22 of 1999 concerning regional government was revised by Law Number 32 of 2004, and lastly revised by Law Number 23 of 2014.

[62] Presidential Decree (KEPPRES) Number 7 of 2020. Task Force for Acceleration

[63] Anonymous, "Doesn't Pass the Discussion in DPRD The Corona Virus Handling Budget is Vulnerable to being Misled", via https://www.mistar.id/medan/taklalui-pembahanan-di-dprdanggaran-penanganan-coronarentandiselewengkan/, accessed on September 9, 2020 ., at 10:10 pm.

[64] Asshiddiqie, Jimly, Indonesian Constitution and Constitutionalism, (Jakarta: Secretariat and Registrar of the Indonesian Constitutional Court, 2006). 
